Vol. 1, No. 2, Mei 2020, pp. 41-52

\title{
PENINGKATAN KECERDASAN KINESTIK ANAK MELALUI PEMBELAJARAN TARI TOPI MALANGAN PADA KELOMPOK B DI RA KALIMOSODO GEDANGAN-MALANG
}

\author{
Yuli Purwanti ${ }^{1}$, Norma Ita Sholihah ${ }^{2}$ \\ Program Studi Pendidikan Islam Anak Usia Dini,Fakultas Tarbiyah, \\ Institut Agama Islam Al-Qolam Malang \\ Normaita@alqolam.ac.id
}

\section{Info Artikel \\ Riwayat Artikel}

Diterima : 31 Maret 2020

Disetujui : 30 April 2020
Kata Kunci :

Kecerdasan Kinestetik, Pembelajaran Tari Topi Malangan

\section{ABSTRAK}

Abstract: The activities of malang hat dance that require basic movement techniques as learning for early childhood. It seems that poor hat dance has difficulty level that requires agility, accuracy, and speed precisely. The purpose of the study was to describe the increase in children's kinesthetic intelligence through malangan hat dance in group $B$ in RA Kalimosodo Gedangan-Malang. Classroom Action Research (Action Research) by applying two cycles through the process of planning, implementation, observation and reflection. Data collection techniques are done by interview, observation, and documentation. The results of the assessment and discussion carried out through Cycle I and Cycle II focused on movement techniques based on agility, accuracy, and speed with the final result of the success indicator process $64 \%$ to $84 \%$. This study experienced an increase between cycles with a percentage of $20 \%$ with a moderate category that manifested the success in the application of the malangan hat dance activity that could improve kinesthetic intelligence in group B children.

Abstrak: Kegiatan tari topi malangan memerlukan teknik-teknik gerakan dasar sebagai pembelajaran untuk anak usia dini. Terlihat tarian topi malangan memiliki tingkat kesulitan yang membutuhkan kelincahan, ketepatan, dan kecepatan secara tepat. Tujuan penelitian untuk mendeskripsikan peningkatan kecerdasan kinestetik anak melalui tari topi malangan pada kelompok B di RA Kalimosodo Gedangan-Malang. Penelitian Tindakan Kelas (Action Research) dengan menerapkan dua siklus melalui proses perencanaan, pelaksanaan, pengamatan dan refleksi. Teknik pengumpulan data dilakukan dengan wawancara, observasi,dan dokumentasi. Hasil penilaian dan pembahasan dilaksanakan melalui Siklus I dan Siklus II terfokus pada teknik gerakan berdasarkan kelincahan, ketepatan, dan kecepatan dengan hasil akhir prosesntase indikator keberhasilan $64 \%$ menjadi $84 \%$. Penelitian ini mengalami peningkatkan antar siklus dengan prosentase $20 \%$ dengan kategori sedang yang mewujudkan adanya keberhasilan dalam penerapan kegiatan tari topi malangan dapat meningkatkan kecerdasan kinestetik pada anak kelompok B. 


\section{PENDAHULUAN}

Pendidikan anak usia dini merupakan pendidikan dasar sebagai penguatan dalam meningkatkan potensinya yang dimiliki anak sejak kecil. Tentu, potensi setiap anak memiliki keistimewaan dan keunikan sejak lahir. Melihat anak telah dibekali dengan potensi yang perlu dikembangkan. Maka, sangat penting potensi tersebut menekankan pada aspek kognitif, aspek afektif, dan aspek psikomotornya. Namun, peneliti terfokus pada perkembangan psikomotornya yang artinya mengarah dalam segi keterampilannya. Dikarenakan anak membutuhkan keterampilan dasar untuk membangun pengalaman-pengalaman barunya. Sehingga, lembaga pendidikan perlu sekali mempersiapkan fasilitas yang dapat menunjang sarana-prasanan dalam mengembangkan kemampuan anak usia dini. ${ }^{1}$ Kemampuan yang dimiliki akan memberikan stimulus dalam mengeksplorasi kebutuhan akal, pikiran dan mengontrol perasaannya sejak lahir. Oleh karena itu, peran pendidik dan orangtua memberikan dukungan dan dorongan untuk anak terhadap potensinya.

Sejalan dengan kajian pendidikan berdasarkan Ki Hajar Dewantara (dalam Suryadi \& Ulfa, 2013) mengemukakan secara eksplisit bahwasannya semua konsep pendidikan yang telah dipersiapkan memiliki tujuan untuk mengembangkan kecerdasan anak. ${ }^{2}$ Akan tetapi, anak mempunyai kemampuan yang dapat membangun pengetahuan untuk berkreatifitas secara mandiri. Ibaratkan menanam benih jagung tidak bisa menjadi benih padi, begitupula sejalan dengan adanya kecerdasan majemuk, Ki Hajar Dewantara pun meyakini bahwa tumbuh kembangnya seorang anak mengikuti perkembangan yang berada pada lingkungan sekitar, khususnya pendidikan pertama dan utama yang di bangun sebagai fondasi dalam lingkungan keluarga untuk meningkatkan kecerdasan majemuk anak.

Teori gadner tentang delapan aspek kecerdasan majemuk, meliputi kecerdasan berbahasa (linguistic), kecerdasan logika-matematika, kecerdasan fisik/kinestetik, kecerdasan spasial, kecerdasan musikal, kecerdasan intrapersonal, kecerdasan interpersonal dan kecerdasan naturalis. Tetapi dalam penerapan di Indonesia ditambahkan menjadi sembilan kecerdasan yaitu kecerdasan spiritual (Sujiono, 2010; Musfiroh, 2008). ${ }^{3}$ Pada dasarnya anak memiliki kecerdasan tersebut sejak lahir. Namun, semua kecerdasan yang dimiliki anak tentu berbeda dalam perkembangan. Sehingga, pendidik dan orangtua hanya memberikan fasilitas dalam mengembangkan potensi dalam menunjang kecerdasannya secara lebih mendalam. Hal tersebut menjadi bentuk evaluasi bahwasannya kecerdasan yang dimiliki anak, dapat dieksplorasi dan dikembangkan secara optimal melalui aktivitas yang di latih dan di bangun secara terorganisir. Peneliti membangun

\footnotetext{
${ }^{1}$ Departemen Pendidikan Nasional. (2004). Kurikulum 2004 Standart kompetensi TK dan Roudlotul Athfal. Jakarta : Depdiknas.

${ }^{2}$ Suyadi \& Ulfah,M. (2013). Konsep Dasar PAUD. Bandung : PT.Remaja Rosdakarya.

${ }^{3}$ Sujiono (2010). Bermain Kreatif Berbasis Kecerdasan Jamak. Jakarta : Indeks.
} 
kecerdasan kinestetik melalui tari topi malang dalam konsep belajar anak sebagai pengenalan budaya tari-tarian yang dapat berkontribusi meningkatkan fisik motoriknya secara sederhana.

Rancangan kegiatan yang diperlukan menekankan pada gerak fisik motorik, anak yang terlihat hanya beberapa anak masih lambat dan kurang bersemangat. Sehingga, kecerdasan kinestetik yang mereka miliki belum berkembang secara baik. Terkadang anak-anak terlihat masih canggung dalam bergerak, malu-malu dan kurang percaya diri dalam menggerakan badannya. Hal ini dapat di lihat dari kegiatan senam pagi yang dilaksanakan sebelum kegiatan pembelajaran berlangsung. Hal ini membuktikan bahwa perkembangan anak di RA Kalimosodo memerlukan stimulasi yang menekankan pada aspek fisik motorik anak guna meningkatkan kecerdasan kinestetik melalui tarian tradisional untuk anak usia 5-6 tahun.

Idealnya, pada rentang usia 5-6 tahun anak mampu melakukan gerakan tubuh secara simbolis. Menurut Wulandari, (2015) mengatakan bahwa teknik mengembangkan gerak tubuh melalui nyanyian dan iringan musik, menyelaraskan antara pikiran dan tubuh (koordinasi tubuh), mengembangkan kelincahan, kekuatan dan keseimbangan tubuh menjadi kebutuhan pada kegiatan tari-tarian. Serta, mengkoordinasi mata dengan tangan dan kaki. ${ }^{4}$ Oleh karena itu, diperlukan stimulasi yang mampu mengembangkan kemampuan dan potensi yang dimiliki oleh anak usia dini termasuk kecerdasan kinestetik, khususnya di kelompok B.

Salah satu cara untuk meningkatkan kecerdasan kinestetik anak melalui pembelajaran menari tarian tradisional di RA Kalimosodo yang dilaksanakan rutin pada setiap hari Jum'at pukul 09.00 WIB sampai dengan 10.30 WIB. Sehingga, prespektif pada kegiatan menari dapat menunjang kemampuan anak dalam mengembangkan dan mengekspresikan pikiran melalui bentuk gestur tubuh dengan iringan lagu ataupun musik. ${ }^{5}$ Selain itu, prespektif tersebut dapat meningkatkan kecerdasan kinestetik yang mengarah pada aspek motorik halus dan kasar pada anak melalui pembelajaran tari topi malangan.

Pembelajaran tari topi malangan di rasa tepat diberikan kepada anak kelompok B. Dimana, tari topi malangan memiliki jenis tari kreasi yang memang sengaja diciptakan oleh Ikatan Guru Raudhatul Athfal (IGRA) kabupaten Malang untuk meningkatkan kecerdasan kinestetik anak di usia RA. Tari topi malangan merupakan tari kreasi khas Malang yang desain ragam geraknya disesuaikan dengan perkembangan anak usia dini yang cenderung energik, ceria dan penuh kelucuan. Tari topi malangan ini juga sudah di uji cobakan serta digebyarkan secara masal oleh anak-anak RA se-Kabupaten Malang pada tahun 2015 di Stadion Kanjuruhan Malang.

\footnotetext{
${ }^{4}$ Wulandari, R,T (2015). Pengetahuan Koreografi Untuk Anak Usia Dini. Malang : Universitas Negeri Malang.

${ }^{5}$ Rachmi, T.,(2008). .Keterampilan Musik dan Tari. Jakarta ; Universitas Terbuka.
} 
Penerapan tari topi malangan ini diciptakan dengan iringan musik gamelan khas Malang yang menggambarkan kegembiraan anak-anak dengan memakai properti topi yang dapat dimainkan sesuai dengan iringan musik (Wulandari, 2015; Pekerti, 2016) ${ }^{6}$. Tari ini menunjang motorik halus dapat dikembangkan melalui gerakan memegang topi sebagai properti tari untuk merasakan kasar dan halus benda tersebut. Serta, melalukan gerakan koordinasi antara mata, tangan dan kaki dengan dipadukan iringan musik.

Strategi kegiatan tari topi malangan menerapakan teknik gerakan melompat, gerakan kuda-kuda atau gerakan mengangkat satu kaki akan melatih kekuatan kaki anak usia dini, gerakan berjinjit dan berjalan dengan satu kaki dapat melatih keseimbangan badan. ${ }^{7}$ Selain itu, ragam gerak tari juga melatih kelincahan dan kelenturan tubuh anak usia dini.

Tujuan penelitian untuk mendeskripsikan pembelajaran tari topi malangan sebagai upaya untuk meningkatkan kecerdasan kinestetik anak usia dini. Untuk mendeskripsikan sejauh mana pembelajaran tari topi malangan dapat meningkatkan kecerdasan anak usia dini di kelompok B RA Kalimosodo Sumberrejo GedanganMalang.

\section{METODE}

Penelitian yang digunakan berupa Penelitian Tindakan Kelas (action research). Menurut Arikunto (2010) mengatakan bahwa PTK memerlukan 3 tahap sesuai dengan prosedure yang berbentuk pra tindakan siklus, siklus I dan siklus II dalam tahap menggunakan metode penelitian PTK meliputi planning, action \& observation, dan reflection. ${ }^{8}$ Kemudian, berputar lalu terjadi perbaikan atau peningkatan yang diharapkan. Penelitian ini dilaksanakan selama enam kali pertemuan.

Penelitian tindakan kelas adalah kajian sistematik dari upaya perbaikan pelaksanaan praktek pendidikan oleh sekelompok pendidik dengan melakukan tindakan-tindakan dalam pembelajaran ${ }^{9}$. Berdasarkan refleksi mereka mengenai hasil dari tindakan-tindakan tersebut.

Subyek penelitian dalam penelitian ini adalah anak Kelompok B RA Kalimosodo Desa Sumberrejo Kecamatan Gedangan Kabupaten Malang yang berjumlah 26 anak yang terdiri dari 6 anak perempuan, 20 anak laki-laki.

Teknik pengumpulan data dilakukan dengan wawancara, observasi, dokumentasi diketahui bahwa selama melaksanakan pengamatan dalam kegiatan pembelajaran anak kelompok B di RA Kalimosodo Desa Sumberrejo GedanganMalang. Dimana, pendidik memfokuskan pada kecerdasan kinestetik anak yang

\footnotetext{
${ }^{6}$ Pekerti, W. (2016). Metode Pengembangan Seni. Tangerang Selatan : Universitas Terbuka.

${ }^{7}$ Soedarsono (1978). Pengantar Komposisi Tari . Yogyakarta: ASTI.

${ }^{8}$ Arikunto, S.(2010). Prosedur Penelitian Suatu Pendekatan Praktik. Jakarta: Rineka Cipta

${ }^{9}$ Wardhani, IGAK (2014). Penelitian Tindakan Kelas. Jakarta: Universitas Terbuka.
} 
menekankan pada keterampilan gerak dasar dalam tarian untuk anak dengan menggunakan properti yaitu topi. Agar dapat membangun pengalaman-pengalaman baru anak sesuai dengan kemampuannya.

Analisis data menggunakan (mixmethod). Dimana, data yang dihasilkan berupa kualitatif-kuantitatif yaitu menggambarkan bentuk fakta sesuai data secara deskriptif yang diperoleh dengan tujuan mendeskripsikan kemampuan anak didik dalam peningkatan kecerdasan kinestetik melalui praktek tari topi malangan. Selain itu, dapat memperoleh data satistik dari respon anak didik ketika mengikuti kegiatan tari topi malangan membuat hasil karya berupa gerakan sesuai dengan irama selama proses aktivitas berlansung berdasarkan tahap siklus I dan siklus II dengan fokus indikator pada aspek kekuatan dan kelincahan, aspek koordinasi mata, tangan dan kaki serta memanipulasi objek, aspek keluwesan dan kelenturan, aspek mengontrol dan aspek mengatur tubuh.

\section{HASIL DAN PEMBAHASAN}

Berdasarkan paparan data penelitian terhadap anak kelompok B di RA Kalimosodo Sumberrejo melalui 2 siklus penelitian, diperoleh hasil penelitian bahwa pembelajaran tari topi malangan dapat meningkatkan kecerdasan kinestetik anak pada kelompok B di RA Kalimosodo Sumberrejo. Penerapan metode demostrasi dapat membantu anak mempelajari dan menghafal gerakan Tari Topi Malangan dengan lebih mudah, karena pada dasarnya karakteristik anak usia dini adalah bersifat imitatif. Sehingga, anak lebih cepat merekam dan mengingat apa yang ia lihat langsung. Pembelajaran tari topi malangan yang dilakukan secara bertahap ini pun di rasa lebih efektif dan lebih cepat di hafal oleh anak. Dengan iringan musik dari gamelan yang memiliki irama khas mampu membentuk nuansa dan mendorong anak untuk lebih aktif, lebih percaya diri dan lebih cepat menghafal.

Adapun sembilan gerakan tari topi malangan yang telah dipelajari oleh anak untuk mengembangkan indikator kecerdasan kinestetik kekuatan dan kelincahan, koordinasi mata, tangan, dan kaki serta memanipulasi objek serta keluwesan dan kelenturan sebagai indikator keberhasilan. Begitu pula pada tiga kriteria penilaian dalam pengembangan kemampuan mengontrol dan mengatur tubuh ketika mempraktekkan gerakan menari.

Pertama, gerakan 1 pada siklus I indikator keberhasilan mencapai $77 \%$ sedangkan pada siklus II mencapai $100 \%$ dan terjadi peningkatan sebesar $23 \%$. Kedua, gerakan 2 pada siklus I indikator keberhasilan mencapai 38\%. Sedangkan, pada siklus II mencapai 77\% dan terjadi peningkatan 39\%. Ketiga, gerakan 3 pada siklus I indikator keberhasilan mencapai 54\%. Sedangkan, pada siklus II mencapai $92 \%$ dan terjadi peningkatan $38 \%$.

Kriteria penilaian keselarasan gerak tangan dan kaki. Pertama, siklus I indikator keberhasilan mencapai 62\%. Sedangkan, pada siklus II mencapai 69\% dan terjadi peningkatan 7\%. Kedua, gerakan 4 pada siklus I indikator keberhasilan mencapai 54\%. Sedangkan, pada siklus II mencapai $77 \%$ dan terjadi peningkatan 
23\%. Ketiga, gerakan 5 pada siklus I indikator keberhasilan mencapai $69 \%$. Sedangkan, pada siklus II mencapai $85 \%$ dan terjadi peningkatan $16 \%$. Keempat, gerakan 6 pada siklus I indikator keberhasilan mencapai 85\%. Sedangkan, pada siklus II mencapai $100 \%$ dan terjadi peningkatan $15 \%$.

Kriteria penilaian ketepatan gerak dengan iringan music. Pertama, siklus I indikator keberhasilan mencapai $62 \%$. Sedangkan, pada siklus II mencapai $77 \%$ dan terjadi peningkatan 15\%. Kedua, gerakan 7 pada siklus I indikator keberhasilan mencapai $38 \%$. Sedangkan, pada siklus II mencapai $69 \%$ dan terjadi peningkatan $31 \%$. Ketiga, gerakan 8 pada siklus I indikator keberhasilan mencapai $69 \%$. Sedangkan, pada siklus II mencapai $85 \%$ dan terjadi peningkatan $16 \%$. Keempat, Gerakan 9 pada siklus I indikator keberhasilan sudah mencapai 100\% dan tetap dipertahankan hingga siklus II tetap sebesar $100 \%$ dan sehingga terjadi peningkatan $0 \%$.

Krieria penilaian kemampuan mengontrol dan mengatur tubuh pada siklus I indikator keberhasilan mencapai 46\%. Sedangkan, pada siklus II mencapai $69 \%$ sehingga terjadi peningkatan yang signifikan sebesar $23 \%$.

Pada bagian refleksi ini akan dikemukakan beberapa hal tentang proses pelaksanaan peningkatan kecerdasan kinestetik anak pada kelompok B di RA Kalimosodo melalui pembelajaran tari topi malangan. Pelaksanaan pembelajaran siklus I dilaksanakan selama tiga hari dan dapat terlaksana dengan baik dan lancar. Namun, masih belum mencapai hasil yang maksimal dan peningkatan yang signifikan. Terutama pada gerakan ukel tangan kanan kiri dan kemampuan dalam menguasai ruang gerak. Persentase anak yang mampu melakukan gerakan ukel tangan kanan kiri dan gerakan jalan egol buka tutup topi hanya 38\%. Begitu pula persentase anak yang mampu menguasai ruang gerak masih menunjukkan angka $46 \%$. Sedangkan, persentase keberhasilan rata-rata $63 \%$. Sehingga, perlu perbaikan pada siklus II.

Tabel 4.1 Hasil Observasi Keseluruhan Gerakan Siklus 1

\begin{tabular}{|c|c|c|c|c|c|c|}
\hline \multirow[t]{2}{*}{ No } & \multirow{2}{*}{$\begin{array}{l}\text { Indikator } \\
\text { Kecerdasan } \\
\text { Kinestetik }\end{array}$} & \multirow[t]{2}{*}{ Uraian Gerakan } & \multirow[t]{2}{*}{$\begin{array}{l}\text { Gerakan } \\
\text { ke }\end{array}$} & \multicolumn{3}{|c|}{$\begin{array}{l}\text { Indikator } \\
\text { Keberhasilan }\end{array}$} \\
\hline & & & & $\mathbf{M}$ & TM & KET \\
\hline \multirow[t]{3}{*}{1} & \multirow[t]{3}{*}{$\begin{array}{l}\text { Kekuatan dan } \\
\text { kelincahan }\end{array}$} & $\begin{array}{l}\text { Berjalan berjinjit } \\
\text { sambil mengangkat } \\
\text { topi }\end{array}$ & 1 & $77 \%$ & $23 \%$ & $\mathrm{BSH}$ \\
\hline & & $\begin{array}{l}\text { Berjalan melompat } \\
\text { sambil mengangkat } \\
\text { topi di atas kepala }\end{array}$ & 6 & $85 \%$ & $15 \%$ & BSB \\
\hline & & $\begin{array}{l}\text { Tampen dan inter- } \\
\text { inter topi }\end{array}$ & 8 & $69 \%$ & $31 \%$ & $\mathrm{BSH}$ \\
\hline 2 & $\begin{array}{l}\text { Koordinasi } \\
\text { mata, tangan }\end{array}$ & $\begin{array}{l}\text { Berjalan sambil } \\
\text { memutar topi ke } \\
\text { kanan-kiri }\end{array}$ & 3 & $54 \%$ & $46 \%$ & MB \\
\hline
\end{tabular}




\begin{tabular}{|c|c|c|c|c|c|c|}
\hline & $\begin{array}{l}\text { dan kaki serta } \\
\text { memanipulasi } \\
\text { objek }\end{array}$ & $\begin{array}{l}\text { Duduk sambil } \\
\text { memainkan topi ke } \\
\text { kanan-kiri diikuti } \\
\text { gerakan godegan } \\
\text { kepala }\end{array}$ & 5 & $69 \%$ & $31 \%$ & $\mathrm{BSH}$ \\
\hline & & $\begin{array}{l}\text { Duduk simpuh } \\
\text { sambil awe-awe } \\
\text { dan tepuk paha }\end{array}$ & 9 & $\begin{array}{l}100 \\
\%\end{array}$ & $0 \%$ & BSB \\
\hline \multirow[t]{3}{*}{3} & \multirow{3}{*}{$\begin{array}{l}\text { Keluwesan } \\
\text { dan } \\
\text { kelenturan }\end{array}$} & $\begin{array}{l}\text { Jalan egol buka } \\
\text { tutup topi }\end{array}$ & 2 & $38 \%$ & $62 \%$ & $\mathrm{BB}$ \\
\hline & & $\begin{array}{l}\text { Gejuk kaki } \\
\text { kanan-kiri sambil } \\
\text { memutar topi }\end{array}$ & 4 & $54 \%$ & $46 \%$ & $\mathrm{MB}$ \\
\hline & & $\begin{array}{l}\text { Ukel tangan kanan } \\
\text { dan kiri sambil } \\
\text { gejuk }\end{array}$ & 7 & $38 \%$ & $62 \%$ & BB \\
\hline \multirow[t]{3}{*}{4} & \multirow{3}{*}{$\begin{array}{l}\text { Mengontrol } \\
\text { dan mengatur } \\
\text { tubuh }\end{array}$} & $\begin{array}{l}\text { Keselarasan gerak } \\
\text { tangan dan kaki }\end{array}$ & - & $62 \%$ & $38 \%$ & $\mathrm{MB}$ \\
\hline & & $\begin{array}{l}\text { Ketepatan gerak } \\
\text { dengan iringan } \\
\text { music }\end{array}$ & - & $62 \%$ & $38 \%$ & $\mathrm{BSH}$ \\
\hline & & $\begin{array}{l}\text { Mampu menguasai } \\
\text { ruang gerak }\end{array}$ & - & $46 \%$ & $54 \%$ & $\mathrm{MB}$ \\
\hline
\end{tabular}

Saat pelaksanaan pembelajaran tari topi malangan pada umumnya anak terlihat senang dan antusias karena tari ini memakai properti topi untuk memperjelas makna tujuan tari tersebut. Terlihat dari hasil tabel 4.1 dengan nilai rata-rata siklus 1 pada kategori mampu mencapai prosentase $63 \%$ masuk kategori tinggi. Sedangkan, kategori tidak mampu mencapai prosentase $37 \%$ masuk kategori rendah. Selain itu, gerakannya unik dan memakai iringan musik tari yang berirama menyenangkan sehingga anak tertarik untuk mengikutinya. Namun, masih ada beberapa anak yang kurang bersemangat dan terlihat kurang percaya diri dalam mengikuti gerakan tari tersebut. Setelah mengevaluasi hasil siklus I ada beberapa kendala yang ditemui, meliputi pertama, masih ada beberapa anak yanag kurang tertib dan mengganggu teman ketika pelaksanaan pembelajaran tari. Kedua, pada saat menari masih ada beberapa anak yang tidak mampu menari mengikuti iringan musik. Ketiga, anak-anak masih sering lupa urutan gerakan tari. Keempat, anak masih terlihat kurang percaya diri dalam melakukan gerakan tari. Kelima, kesulitan melakukan gerakan ukel tangan kanan kiri. Keenam, masih ada yang kurang bebas melakukan gerakan atau belum mampu menguasai ruang gerak.

Beberapa hal yang direncanakan yang telah di evaluasi dari siklus I sebagai upaya perbaikan pada siklus II, meliputi mengulang kembali gerakan ukel tangan kanan kiri sampai anak mampu melakukan sendiri tanpa bantuan guru, menggunakan metode demonstrasi untuk memperagakan kembali gerakan tari secara bertahap dengan diiringi musik, membangun rasa percaya diri anak sehingga 
anak mampu bergerak bebas dan tidak terlihat malu-malu dalam melakukan gerakan tari dengan memberikan pujian ketika anak bisa melakukan gerkan tari, dan melakukan koordinasi dengan guru sebagai kolaboratif peneliti dalam proses pembelajaran tari. Terbukti keberhasilan anak yang mampu melakukan gerakan tari topi malangan di mulai dari gerakan 1 sampai 9 dan 3 dengan kriteria penilaian berdasarkan indikator mengontrol dan mengatur tubuh mencapai prosentase $83 \%$ dan dapat dikatakan berkembang sangat tinggi.

\section{Tabel 4.2 Hasil Akhir Observasi Keseluruhan Gerakan Siklus 1I}

\begin{tabular}{|c|c|c|c|c|c|c|}
\hline \multirow[t]{2}{*}{ No } & \multirow{2}{*}{$\begin{array}{c}\text { Indikator } \\
\text { Kecerdasan } \\
\text { Kinestetik }\end{array}$} & \multirow[t]{2}{*}{ Jenis Gerakan } & \multirow[t]{2}{*}{ Kode } & \multicolumn{3}{|c|}{$\begin{array}{c}\text { Indikator } \\
\text { Keberhasilan }\end{array}$} \\
\hline & & & & $\mathbf{M}$ & TM & KET. \\
\hline \multirow[t]{3}{*}{1} & \multirow[t]{3}{*}{$\begin{array}{l}\text { Kekuatan dan } \\
\text { kelincahan }\end{array}$} & $\begin{array}{l}\text { Berjalan berjinjit } \\
\text { sambil mengangkat } \\
\text { topi }\end{array}$ & 1 & $100 \%$ & $0 \%$ & BSB \\
\hline & & $\begin{array}{l}\text { Berjalan melompat } \\
\text { sambil mengangkat } \\
\text { topi di atas kepala }\end{array}$ & 6 & $100 \%$ & $0 \%$ & BSB \\
\hline & & $\begin{array}{l}\text { Tampen dan inter- } \\
\text { inter topi }\end{array}$ & 8 & $85 \%$ & $15 \%$ & BSB \\
\hline \multirow[t]{3}{*}{2} & \multirow{3}{*}{$\begin{array}{l}\text { Koordinasi } \\
\text { mata, tangan } \\
\text { dan kaki serta } \\
\text { memanipulasi } \\
\text { objek }\end{array}$} & $\begin{array}{l}\text { Berjalan sambil } \\
\text { memutar topi ke } \\
\text { kanan-kiri }\end{array}$ & 3 & $92 \%$ & $8 \%$ & $\mathrm{BSH}$ \\
\hline & & $\begin{array}{l}\text { Duduk sambil } \\
\text { memainkan topi ke } \\
\text { kanan-kiri diikuti } \\
\text { gerakan godegan } \\
\text { kepala }\end{array}$ & 5 & $85 \%$ & $15 \%$ & BSB \\
\hline & & $\begin{array}{l}\text { Duduk simpuh sambil } \\
\text { awe-awe dan tepuk } \\
\text { paha }\end{array}$ & 9 & $100 \%$ & $0 \%$ & BSB \\
\hline \multirow[t]{3}{*}{3} & \multirow{3}{*}{$\begin{array}{l}\text { Keluwesan } \\
\text { dan } \\
\text { kelenturan }\end{array}$} & $\begin{array}{l}\text { Jalan egol buka tutup } \\
\text { topi }\end{array}$ & 2 & $77 \%$ & $23 \%$ & BSB \\
\hline & & $\begin{array}{l}\text { Gejuk kaki kanan- } \\
\text { kiri sambil memutar } \\
\text { topi }\end{array}$ & 4 & $77 \%$ & $23 \%$ & $\mathrm{BSH}$ \\
\hline & & $\begin{array}{l}\text { Ukel tangan kanan } \\
\text { dan kiri sambil gejuk }\end{array}$ & 7 & $69 \%$ & $31 \%$ & $\mathrm{BSH}$ \\
\hline \multirow[t]{3}{*}{4} & \multirow{3}{*}{$\begin{array}{l}\text { Mengontrol } \\
\text { dan mengatur } \\
\text { tubuh }\end{array}$} & $\begin{array}{l}\text { Keselarasan gerak } \\
\text { tangan dan kaki }\end{array}$ & - & $69 \%$ & $31 \%$ & $\mathrm{BSH}$ \\
\hline & & $\begin{array}{l}\text { Ketepatan gerak } \\
\text { dengan iringan musi }\end{array}$ & - & $77 \%$ & $23 \%$ & BSB \\
\hline & & $\begin{array}{l}\text { Mampu menguasai } \\
\text { ruang gerak }\end{array}$ & - & $69 \%$ & $31 \%$ & BSB \\
\hline & RAT & RATA & & $83 \%$ & $17 \%$ & BSB \\
\hline
\end{tabular}


Berdasarkan penelitian siklus II menunjukkan kemampuan anak meningkat dibandingkan siklus I. Rincian data yang diperoleh pada kemampuan anak mencapai prosentase $83 \%$ dikategorikan sangat tinggi. Sedangkan, pada hasil tidam mampu mencapai 17\% dikategorikan sangat rendah. Sehingga, sangat terlihat perubahan yang sangat signifikan bahwa peningkatan hasil kemampuan anak dari siklus I dan siklus II. Hal tersebut dapat dilihat dari tabel 4.2, sebagai berikut:

Tabel 4.3 Prosentase Indikator Keberhasilan Siklus I dan Siklus II

\begin{tabular}{|c|c|c|c|c|c|c|c|c|c|}
\hline \multirow[t]{2}{*}{ No } & \multirow{2}{*}{$\begin{array}{c}\text { Indikator } \\
\text { Kecerdasan } \\
\text { Kinestetik }\end{array}$} & \multirow{2}{*}{$\begin{array}{c}\text { Jenis } \\
\text { Gerakan }\end{array}$} & \multirow[t]{2}{*}{ Kode } & \multicolumn{6}{|c|}{ Indikator Keberhasilan } \\
\hline & & & & Sikl & IS I & Siklu & S II & Pening & zatan \\
\hline \multirow[t]{3}{*}{1} & \multirow[t]{3}{*}{$\begin{array}{l}\text { Kekuatan } \\
\text { dan } \\
\text { kelincahan }\end{array}$} & $\begin{array}{l}\text { Berjalan } \\
\text { berjinjit } \\
\text { sambil } \\
\text { mengangkat } \\
\text { topi }\end{array}$ & 1 & $77 \%$ & \multirow[t]{3}{*}{$77 \%$} & $100 \%$ & \multirow[t]{3}{*}{$95 \%$} & $23 \%$ & \multirow[t]{3}{*}{$18 \%$} \\
\hline & & $\begin{array}{l}\text { Berjalan } \\
\text { melompat } \\
\text { sambil } \\
\text { mengangkat } \\
\text { topi di atas } \\
\text { kepala }\end{array}$ & 6 & $85 \%$ & & $100 \%$ & & $15 \%$ & \\
\hline & & $\begin{array}{l}\text { Tampen dan } \\
\text { inter-inter } \\
\text { topi }\end{array}$ & 8 & $69 \%$ & & $85 \%$ & & $16 \%$ & \\
\hline \multirow[t]{3}{*}{2} & \multirow{3}{*}{$\begin{array}{l}\text { Koordinasi } \\
\text { mata, tangan } \\
\text { dan kaki } \\
\text { serta } \\
\text { memanipula } \\
\text { si objek }\end{array}$} & $\begin{array}{l}\text { Berjalan } \\
\text { sambil } \\
\text { memutar topi } \\
\text { ke kanan-kiri }\end{array}$ & 3 & $54 \%$ & \multirow{3}{*}{$74 \%$} & $92 \%$ & \multirow{3}{*}{$92 \%$} & $38 \%$ & \multirow{3}{*}{$18 \%$} \\
\hline & & $\begin{array}{l}\text { Duduk sambil } \\
\text { memainkan } \\
\text { topi ke } \\
\text { kanan-kiri } \\
\text { diikuti } \\
\text { gerakan } \\
\text { godegan } \\
\text { kepala }\end{array}$ & 5 & $69 \%$ & & $85 \%$ & & $16 \%$ & \\
\hline & & $\begin{array}{l}\text { Duduk } \\
\text { simpuh } \\
\text { sambil awe- } \\
\text { awe dan } \\
\text { tepuk paha }\end{array}$ & 9 & $100 \%$ & & $100 \%$ & & $0 \%$ & \\
\hline \multirow[t]{3}{*}{3} & \multirow{3}{*}{$\begin{array}{l}\text { Keluwesan } \\
\text { dan } \\
\text { kelenturan }\end{array}$} & $\begin{array}{l}\text { Jalan egol } \\
\text { buka tutup } \\
\text { topi }\end{array}$ & 2 & $38 \%$ & \multirow{3}{*}{$43 \%$} & $77 \%$ & \multirow{3}{*}{$74 \%$} & $39 \%$ & \multirow{3}{*}{$31 \%$} \\
\hline & & $\begin{array}{l}\text { Gejuk kaki } \\
\text { kanan-kiri } \\
\text { sambil } \\
\text { memutar topi }\end{array}$ & 4 & $54 \%$ & & $77 \%$ & & $23 \%$ & \\
\hline & & $\begin{array}{l}\text { Ukel tangan } \\
\text { kanan dan } \\
\text { kiri sambil } \\
\text { gejuk }\end{array}$ & 7 & $38 \%$ & & $69 \%$ & & $31 \%$ & \\
\hline
\end{tabular}




\begin{tabular}{|c|c|c|c|c|c|c|c|c|c|}
\hline \multirow[t]{3}{*}{4} & \multirow{3}{*}{$\begin{array}{l}\text { Mengontrol } \\
\text { dan } \\
\text { mengatur } \\
\text { tubuh }\end{array}$} & $\begin{array}{l}\text { Keselarasan } \\
\text { gerak tangan } \\
\text { dan kaki }\end{array}$ & - & $62 \%$ & \multirow{3}{*}{$56 \%$} & \multirow{2}{*}{$\begin{array}{l}69 \% \\
77 \% \\
\end{array}$} & \multirow{3}{*}{$71 \%$} & \multirow{2}{*}{$\begin{array}{l}7 \% \\
15 \%\end{array}$} & \multirow{3}{*}{$15 \%$} \\
\hline & & $\begin{array}{l}\text { Ketepatan } \\
\text { gerak dengan } \\
\text { iringan musi }\end{array}$ & - & $62 \%$ & & & & & \\
\hline & & $\begin{array}{l}\text { Mampu } \\
\text { menguasai } \\
\text { ruang gerak }\end{array}$ & - & $46 \%$ & & $69 \%$ & & $23 \%$ & \\
\hline & TOTAL RA & I_RATA & & $63 \%$ & & $83 \%$ & & $20 \%$ & \\
\hline
\end{tabular}

Berdasarkan hasil akhir dari peningkatan antara siklus I dan siklus II , terlihat perubahan prosentase yang sangat signifikan dengan rata-rata siklus I mencapai 63\% masuk kategori tinggi. Sedangkan, peningkatan sangat terlihat pada hasil rata-rata siklus II mencapai $83 \%$ masuk kategori sangat tinggi. Sehingga, hasil peningkatan antar kedua siklus mencapai $20 \%$. Hal tersebut telihat dari grafik pada Bagan 4.1, sebagai berikut:

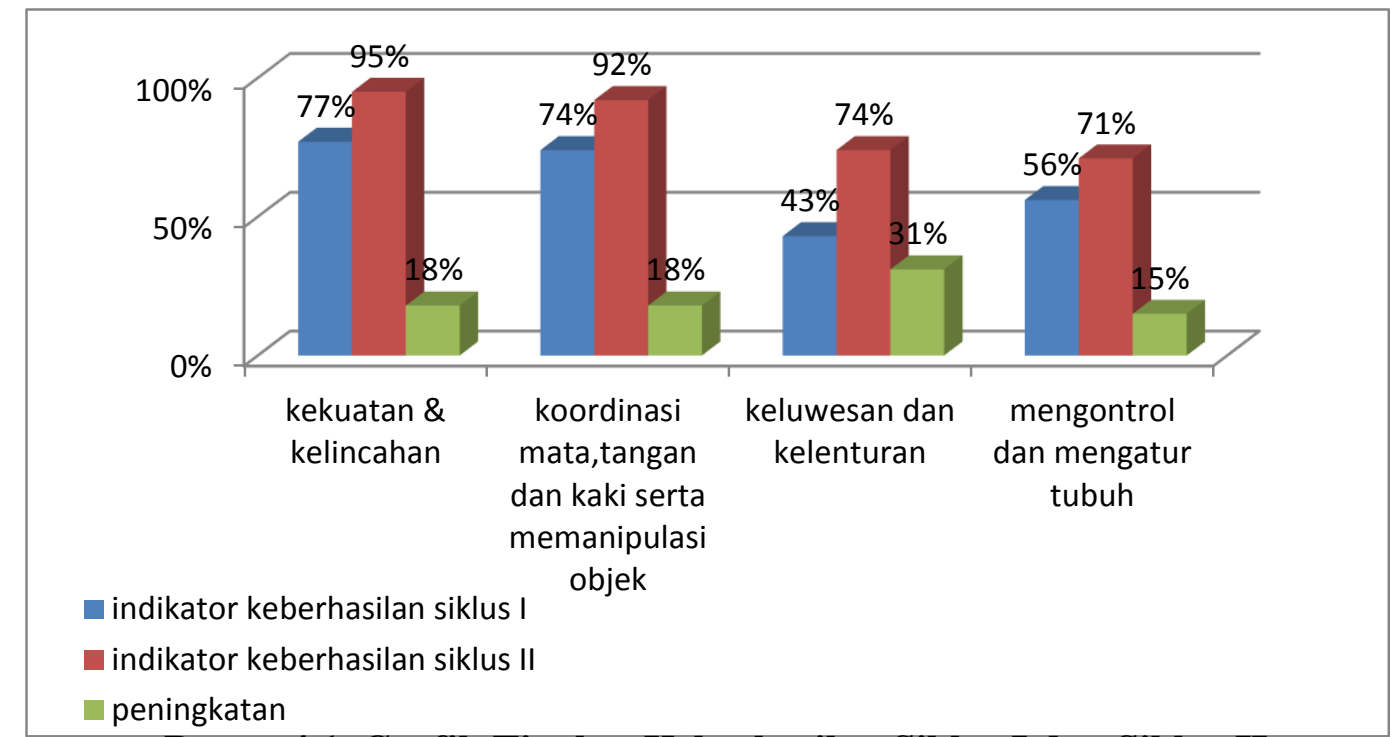

\section{Bagan 4.1 Grafik Tingkat Keberhasilan Siklus I dan Siklus II}

Berdasarkan bagan 4.1 dapat disimpulkan bahwasannya Terbukti keberhasilan penerapan tari topi malangan dengan tujuan meningkatkan kecerdasan kinestik anak memiliki hasil yang sangat signifikan. Terlihat dari hasil keseluruhan setiap siklus dengan enam kali pertemuan berdasarkan indikator keberhasilan. Sehingga, pendidik sangat penting menerapkan pembelajaran yang menekankan pada keterampilan anak. Dimana, keterampilan anak menjadi salah satu potensi yang dikembangkan, didukung, dan difasilitasi sesuai dengan minat dan keinginannya. Sehingga, bakat keterampilan akan menambah wawasan anak dalam mengembangkan bidang kemampuannya.

\section{SIMPULAN DAN SARAN}

Berdasarkan hasil penelitian tentang peningkatan kecerdasan kinestetik anak kelompok B di RA Kalimosodo Sumberrejo melalui pembelajaran Tari Topi Malangan sudah mencapai hasil yang baik. Hal tersebut dapat disimpulkan bahwa 
pertama, Penerapan pembelajaran Tari Topi Malangan untuk meningkatkan kecerdasan kinestetik anak pada kelompok B di Raudhatul Athfal Kalimosodo Sumberejo dilakukan melalui metode demonstrasi yang dilakukan oleh guru dan kemudian diikuti oleh unjuk kerja anak setelah gerakan dicontohkan oleh guru. Kegiatan pembelajaran tari ini dilakukan secara bertahap agar memperoleh hasil yang maksimal. Pada siklus I gerakan yang diajarkan tidak dilakukan secara menyeluruh, melainkan dilakukan secara bertahap yaitu diberikan 3 gerakan pada setiap pertemuan. Sedangkan pada siklus II setiap pertemuan seluruh gerakan dipraktekkan secara bersamaan untuk mempermudah observasi terhadap anak yang belum menguasai gerakan Tari Topi Malangan. Kedua, diterapkannya pembelajaran Tari Topi Malangan, kecerdasan kinestetik anak meningkat. Hasil penelitian menunjukkan perkembangan rata-rata kecerdasan kinestetik anak pada siklus I dan siklus II mengalami peningkatan. Pada siklus I kecerdasan kinestetik anak mencapai nilai rata-rata indikator keberhasilan 63\%. Sedangkan, pada siklus II kecerdasan kinestetik anak, mencapai rata-rata indikator keberhasilan 83\%. Jadi peningkatan pada siklus I ke siklus II mengalami peningkatan $20 \%$ sesuai dengan yang diharapkan.

Berdasarkan kesimpulan yang peneliti paparkan di atas, maka perlu adanya saran dan perbaikan yang mendukung. Adapun saran-saran tersebut, antara lain pertama, bagi Guru Raudhotul Athfal agar lebih memperhatikan perkembangan kecerdasan kinestetik anak usia dini. Dalam memberikan materi pembelajaran tari kepada anak diharapkan tidak memberikan materi pembelajaran tari yang menyulitkan anak, namun hendaknya memberikan pembelajaran tari yang mudah dan menyenangkan bagi anak sehingga dapat menstimulasi aspek perkembangan kecerdasan jamak yang dimiliki oleh anak.

Kedua, Bagi kepala sekolah RA Kalimosodo Sumberrejo agar pembelajaran tari tidak hanya dijadikan kegiatan ekstra kurikuler saja, namun juga dijadikan kegiatan intrakulikuler yang terintegrasi dalam pembelajaran sehingga meningkatkan kualitas proses pembelajaran dan menjadi alternatif stimulasi dalam meningkatkan kecerdasan kinestetik anak. Ketiga, bagi peneliti lain diharapkan dapat melakukan penelitian yang berkaitan dengan kegiatan tari terutama tari tradisional khas Malang dalam upaya meningkatkan berbagai aspek perkembangan anak usia dini dan menumbuhkan rasa cinta terhadap tanah kelahirannya.

\section{DAFTAR RUJUKAN}

Arikunto, S.(2010). Prosedur Penelitian Suatu Pendekatan Praktik. Jakarta: Rineka Cipta

Departemen Pendidikan Nasional.2004. Kurikulum 2004 Standart kompetensi TK dan Roudlotul Athfal. Jakarta : Depdiknas.

Musfiroh, T., (2008). Pengembangan Kecerdasan Majemuk. Jakarta : Universitas Terbuka. 
Pekerti, W., (2016). Metode Pengembangan Seni. Tangerang Selatan : Universitas Terbuka.

Rachmi, T., (2008). .Keterampilan Musik dan Tari. Jakarta ; Universitas Terbuka.

Soedarsono (1978). Pengantar Komposisi Tari . Yogyakarta: ASTI.

Sugiyono (2010). Metode Penelitian Pendidikan. Bandung: Alfabeta.

Sujiono (2010). Bermain Kreatif Berbasis Kecerdasan Jamak. Jakarta : Indeks.

Suyadi (2012). Buku Panduan Guru Profesional: Penelitian Tindakan Kelas (PTK) dan Penelitian Tindakan Sekolah (PTS). Yogyakarta: Andi Offset

Suyadi (2014). Teori Pembelajaran Anak Usia Dini Dalam Kajian Neurosains. Bandung : Rosdakarya.

Suyadi dan Maulidya Ulfah (2013). Konsep Dasar PAUD. Bandung : PT.Remaja Rosdakarya.

Wardhani, IGAK (2014). Penelitian Tindakan Kelas. Jakarta: Universitas Terbuka.

Wulandari, Retno Tri (2015). Pengetahuan Koreografi Untuk Anak Usia Dini. Malang : Universitas Negeri Malang. 